
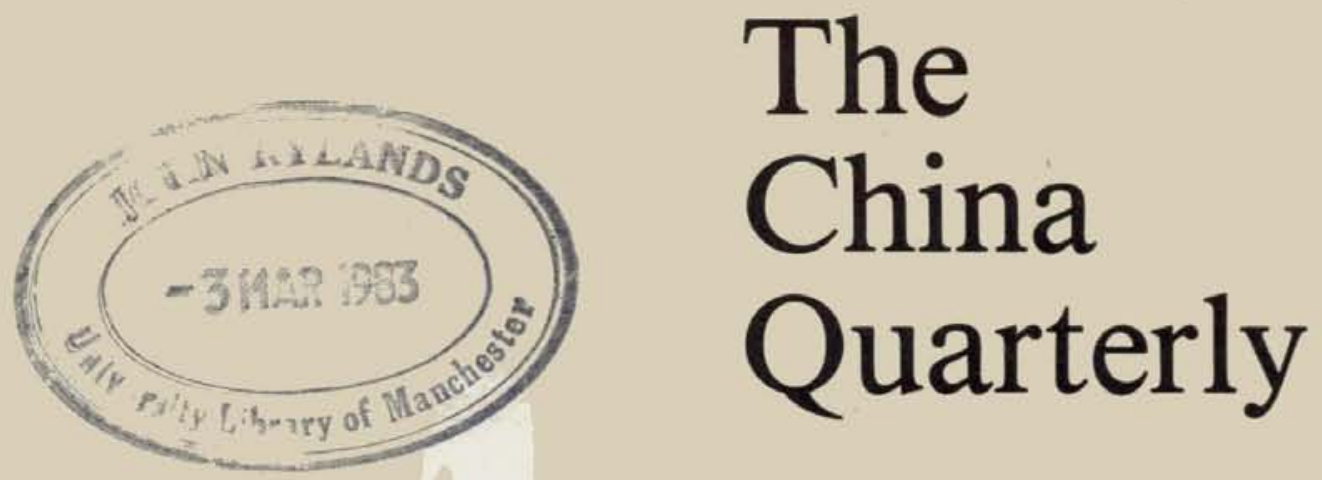

\title{
92
}

December 1982

Kenneth R. Walker James L. Watson Denis Twitchett Dorothy J. Solinger Edel Lancashire Paul Kratochvil Tang Tao Nora Wang Keith Griffin E. B. Vermeer C. Martin Wilbur Hugh D. R. Baker Michel Oksenberg 
Offorint from "Taxes and Investment in Asia and the Pacific" (sponsored by the U.N. Economic and Social Commission for Asia and the Pacific-ESCAP

\section{INVESTMENT AND TAXATION IN}

\section{THE PEOPLE'S \\ REPUBLIC OF CHINA}

fourth expanded edition

Based on latest information just received, this indepth survey concentrates on the current situation and envisaged changes likely to affect investment and taxation. Emphasis is placed on the various forms of undertakings (joint ventures, compensation trade, etc.), exchange control, banking and insurance, and licensing.

Special emphasis is placed on a detailed survey of all Chinese taxes, with relevant tax rates, including those promulgated in connection with the implementation of the "Four Modernizations" (Foreign Enterprise Income Tax, Joint Venture Income Tax, Individual Income Tax, etc).
Prepared in direct cooperation with several top Chinese governmental agencies. Earlier editions received wide acclaim throughout the world (even from several authorities in China itself).

An extensive appendix includes several important agreements between China and other countries; an updated list of the precise addresses of all relevant Chinese authorities (where possible with telex and telephone numbers); and the text of the Joint Venture Law of July 8, 1979 in English, French and German).

\section{Price: 145 Dutch Florins, including postage}

This special survey is included in the complete looseleaf work, TAXES AND INVESTMENT IN ASIA AND THE PACIFIC, without extra charge. Free details upon request.

\section{INTERNATIONAL BUREAU OF FISCAL DOCUMENTATION P.O. Box 20237, 1000 HE Amsterdam, Netherlands}

Telex: 13217 intax nl Tel: (0)20-267726 Cables: FORINTAX 


\section{The China Quarterly}

an international journal for the study of China

\section{December 1982 number $92 \quad £ 3 \cdot 75 \quad \$ 8.50$}

Interpreting Chinese Grain Consumption Statistics

Kenneth R. Walker 575

Chinese Kinship Reconsidered: Anthropological Perspectives on Historical Research James L. Watson

Comment on J. L. Watson's article

Denis Twitchett 623

Politics in Yunnan Province in the Decade of Disorder: Elite Factional Strategies and Central-local Relations, 1967-1980

Dorothy J. Solinger 628

Popeye and the Case of Guo Yidong, alias Bo Yang

Modern Chinese and Linguistic Change

Edel Lancashire 663

Old Tales Retold (Gushi xinbian)

Paul Kratochvil 687

Tang Tao 696

Research Note

Deng Xiaoping: The Years in France

Nora.Wang 698

Comment

Income Differentials in Rural China

Keith Griffin 706

Reply by E. B. Vermeer

Review Articles

J. K. Fairbank: A Fifty-year Memoir

Three Lenses, Focusing

C. Martin Wilbur 714

The Shanghai Connection

Hugh D. R. Baker 720

Michel Oksenberg 723

\section{Book Reviews}

The International Energy Relations of China. By Kim Woodard. Christopher Howe

Chinese Literature for the 1980s, the Fourth Congress of Writers and Artists. Edited by Howard Goldblatt. D. E. Pollard

Wild Lilies: Poisonous Weeds. Edited by Gregor Benton. David S. G. Goodman

Lao She: Zwischen Traum und Wirklichkeit: Erzählungen. Edited by Volker Klöpsch. Elizabeth C. Smith

The Chinese Earth: Stories by Shen Ts'ung-wen. Translated by Ching Ti and Robert Payne. S. Ma

China: Politics and Government. By Tony Saich.

The Government and Politics of the People's Republic of China. By Derek J. Waller. Thomas P. Bernstein

Mandarin Pronunciation Explained With Diagrams: A Companion to R. H. Mathews' Chinese-English Dictionary. By Raymond Huang. Paul Kratochvil 
The Performing Arts in Contemporary China. By Colin Mackerras. David Holm

The Taiwan Success Story: Rapid Growth with Improved Distribution in the Republic of China, 1952-1979. By Shirley W. V. Kuo, Gustav Ranis and John C. H. Fei. W. Klatt

The Future Association of Taiwan with the People's Republic of China. By Dan C. Sanford. Charles T. Cross

La Condition Féminine et les Communistes Chinois en Action: Yan'an 1935-1946. By Hua Chang-ming.

Women of China Imperialism and Women's Resistance 1900-1949. By Bobby Siu. Delia Davin

Trading with China - A Practical Guide. Edited by Colina MacDougall. Susan Ware

Die deutsche Beraterschaft in China, 1927-1938. Militar-WirtschaftAussenpolitik. Edited by Bernd Martin. Hsi-Huey Liang

Indochina: der permanente Konflikt? Edited by Werner Draguhn and Peter Schier.

ASEAN. Ein Weg aus de Unterentwicklung? Grenzen und Moglichkeiten regionaler wirtschaftlicher Zusammenarbeit. By Franz $\mathbf{R}$. Herres. Roger Kershaw

The Politics of Cotton Textiles in Kuomintang China, 1927-1937. By Richard C. Bush. M. C. Bergère

Development and Under-development in Historical Perspective. By Gavin Kitching. E. B. Vermeer

Politisches Theater im Pekinger Frühling 1978 - "Aus der Stille" von Zong Fuxian. Ubersetzung und Kommentar. By Martin Krott. David Holm

China's Foreign Policy in the Arab World, 1955-75. By Hashim S. H. Behbehani.

Soviet-Indian Relations: Issues and Influence. By Robert C. Horn. Gerald Segal

Chinese Democracy. By John H. Fincher. R. Keith Schoppa 753

Book Notes

Books Received

Quarterly Chronicle and Documentation (July-September 1982)

(Compiled by Robert F. Ash)

Contributors

Index for 1982

\section{News, Projects and Appointments}

Future issues of The China Quarterly will include a section reporting news of important academic changes, appointments and projects, as well as announcements of forthcoming conferences and seminars in the field of China studies. Readers and institutions are invited to submit items which will be considered for inclusion in this section. They should be as concise as possible.

(C) Contemporary China Institute, School of Oriental and African Studies, 1982 Printed in Great Britain by The Eastern Press Ltd., London and Reading 


\title{
The China Quarterly
}

\author{
Editor: Brian Hook \\ Assistant Editor: Gail A. Eadie-Duggett \\ Acting Assistant Editor: Murray Mindlin
}

\section{Editorial Board}

Hugh D. R. Baker, School of Oriental and African Studies; Marianne Bastid,* Centre National de la Recherche Scientifique; Thomas P. Bernstein, Columbia; Cyril Birch, Berkeley; Paul H. Ch'en, * School of Oriental and African Studies; John Chinnery,* University of Edinburgh; Jerome A. Cohen, Harvard Law School; Vidya Prakash Dutt, Delhi; John K. Fairbank, Harvard; Albert Feuerwerker, University of Michigan; David S. G. Goodman,* University of Newcastle-upon-Tyne; Christopher Howe,* School of Oriental and African Studies; Shigeru Ishikawa, Aoyama-gakuin University; Ambrose Y. C. King, Chinese University of Hong Kong; Werner Klatt, St. Antony's College, Oxford; Donald W. Klein, Tufts; John W. Lewis, Stanford; Roderick MacFarquhar; Michel Oksenberg, University of Michigan; William L. Parish, Chicago; Dwight Perkins, Harvard; Lucian W. Pye, M.I.T.; Stuart R. Schram,* School of Oriental and African Studies; Benjamin Schwartz, Harvard; G. William Skinner, Stanford; Brunhild Staiger, Hamburg; Tang Tsou, Chicago; Ezra Vogel, East Asian Research Center, Harvard; Frederic Wakeman, Berkeley; Kenneth R. Walker,* School of Oriental and African Studies; Wang Gungwu, Australian National University; J. L. Watson, * School of Oriental and African Studies; Michael Yahuda; * University of Adelaide.

*Members of Executive Committee

\section{Editorial and Business Offices}

Contemporary China Institute, School of Oriental and African Studies, Malet Street, London WCIE 7HP. Telephone 01-637 2388.

\section{Subscription Office}

All subscriptions should be sent to the above address, marked: subscriptions.

\section{Subscription Rates}

£15 or U.S. $\$ 30$ per year, post free. Reduced rates for full-time students of $£ 7.50$ or U.S. $\$ 15$ per year. Individual copies, $\mathbf{\$ 3 . 7 5}$ or U.S. $\$ 8.50$ for current and recent issues, otherwise $£ 4$ or U.S. $\$ 9.50$. Special arrangements can be made for subscribers with areas with currency regulations and for posting by airmail.

\section{Manuscripts}

The China Quarterly welcomes the submission of manuscripts from all scholars, including research students, on all aspects of contemporary China and from all points of view, including those which deal with Taiwan and Overseas Chinese. Articles on China prior to 1949 are also welcome, particularly, but not exclusively, when these relate directly to contemporary China or to the history of the Chinese Communist Party. Articles should be submitted, in triplicate, to the editorial office. They should be typed in double spacing and, preferably, conform to the styling of The China Quarterly.

The China Quarterly is published by the Contemporary China Institute of the School of Oriental and African Studies, London University. The views expressed in articles are those of individual authors and do not necessarily represent the views of the Contemporary China Institute. 


\section{THE TIMES}

Atlas of

World

History

CHINESE LANGUAGE

EDITION

Translated, manufactured and published by The Joint Publishing Company, Beijing

Available in the UK, Europe and America from

Times Books Ltd, 16 Golden Square, London W1R 4BN

Tel. 01-434 3767

Price $£ 65$ : Please add $£ 2.10 p+p$ for $U K, \mathfrak{£} 7.50$ for Europe, $£ 8.50$ for USA

A unique source book for the modern Chinese equivalents of place names, historical names and peoples.

" A major event ", Prof. Lo Rongqi, Beijing University 